\title{
Limnological Study of Mohan Ram Pond District Shahdol, Madhya Pradesh, India
}

\author{
Bramhanand Shukla
}

Department of Zoology, Govt. I.G.H.S. P.G. College Shahdol - 484001, India

\begin{abstract}
The present paper study is water quality analysis of Mohan Ram Pond. The study is carried out Jan.2013-Dec.2013. The Physical and chemical properties of water has been discussed. The pond is not much polluted. Hence it can be used as potable water in Mohan Ram Pond.
\end{abstract}

Keywords: Limnology, Shahdol District, Mohan Ram Pond

\section{Introduction}

Due to Lymnological study in water is very important life supporting material. Every living organism needs water, without which neither the life nor any development is possible. Thus it is very much essential for a healthy growth. But it may become harmful for life, if one uses water polluted with harmful or with toxic substances and poor sanitation. (Gupta and Gupta, 1997, Mishra, et al. 2009, Tewari, et al. 2010, Sirajudeen, et al.2014, Kumar and Kumar 2015) Water quality parameters provide the basis for judging the suitability of water for its designated uses and to improve existing conditions. For optimum development and management for the beneficial uses, current information is needed which is provided by water quality programmes (Lloyd, 1992). We depend on water for domestic needs, irrigation, sanitation and disposal of wastes. The quality and quantity of surface water bodies like lakes and tanks depend upon the climate, catchments, geography of the area and the inputs and outputs both natural and manmade (Gray, 1994). The water quality of lakes can be degraded due to microbiological and chemicals contaminants. In water natural impurities are in very low amounts. Lakes, dams, rivers are important source of fresh water.

The quality of water is described by its physical, chemical and microbial characteristics. But, if some correlations were possible among these parameters, then significant ones would be fairly useful to indicate the quality of water. The study of important, because fluctuation in the water quality has an influence on the biotic communities (Aher and Mane, 2007). This information is important to be communicated to the general public and the Government in order to develop policies for the conservation of the precious fresh water resources (Ali et al., 2000). The aims of this study were designed to monitor seasonal variation in water quality parameter of Mohan Ram Pond so as to assess its status and suitability through the potability and aquaculture point of view and to compare observed levels of studied parameters with the corresponding WHO and BIS guidelines values for drinking-water quality and pisciculture.

\section{Materials and Methods}

Present Study of Physico-chemical parameters was carried out during the period of January, 2013 to December, 2013. By considering the morphometry and human activities sampling sites were selected at different places along the tanks, From all the four stations of pond, water samples were collected from the periphery at about 1 to 1.5 meters depth fortnightly. The water samples were collected in plastic cans of 2-3 lit. Capacity and brought to the laboratory to study various parameters. Temperature and $\mathrm{pH}$ were recorded at the time of sample collection using portable kit. The determination of dissolved oxygen, free carbon dioxide, hardness, chlorides, total alkalinity, inorganic phosphate and nitrate were analysed in the laboratory as per the standard procedure and metrology described by APHA, AWWA, WPCF (1998).

\section{Results and Discussion}

The result of Physical properties of water from Mohan Ram Pond was given in Table $\mathbf{1}$ and the result of chemical properties of water from Mohan Ram Pond was shown in Table 2. 
International Journal of Science and Research (IJSR)

ISSN (Online): 2319-7064

Index Copernicus Value (2013): 6.14 | Impact Factor (2015): 6.391

Table 1: Physical Parameters of Mohan Ram Pond, Shahdol District

\begin{tabular}{|c|c|c|c|c|}
\hline Months & Temp. $\left({ }^{\circ} \mathrm{C}\right)$ & Turbidity (NTU) & Transparency $(\mathrm{cm})$ & $\mathrm{pH}$ \\
\hline Jan. & 22.16 & 2.25 & 40.10 & 7.10 \\
\hline Feb. & 22.48 & 2.90 & 32.45 & 7.65 \\
\hline Mar. & 24.56 & 2.95 & 35.46 & 7.45 \\
\hline Apr. & 26.48 & 1.20 & 32.48 & 7.80 \\
\hline May & 28.64 & 1.45 & 30.40 & 8.10 \\
\hline Jun. & 27.45 & 1.65 & 42.56 & 8.28 \\
\hline Jul. & 26.47 & 1.74 & 39.42 & 8.13 \\
\hline Aug. & 25.12 & 1.56 & 38.85 & 7.12 \\
\hline Sept. & 25.47 & 1.90 & 35.42 & 8.08 \\
\hline Oct. & 24.18 & 0.85 & 44.56 & 8.10 \\
\hline Nov. & 23.56 & 0.68 & 45.26 & 8.26 \\
\hline Dec. & 22.58 & 1.56 & 46.18 & \\
\hline
\end{tabular}

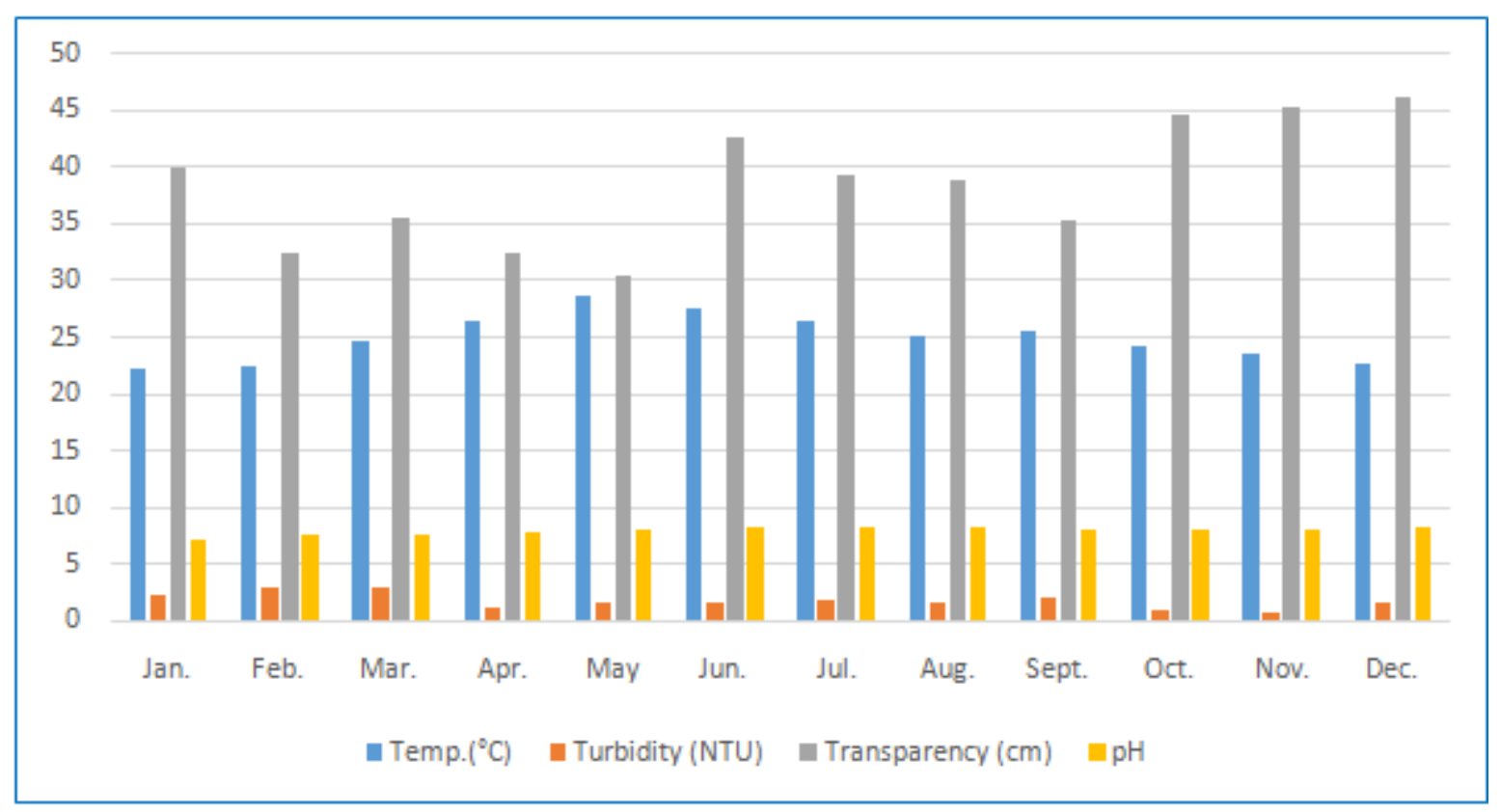

Graph 1: Physical Parameters of Mohan Ram Pond, Shahdol District

Table 2: Chemical Parameters of Mohan Ram Pond, Shahdol District (values are in mg/l)

\begin{tabular}{|c|c|c|c|c|c|c|c|}
\hline Months & $\begin{array}{c}\text { Dissolved } \\
\text { Oxygen }\end{array}$ & Free $\mathrm{CO}_{2}$ & Alkalinity & Hardness & Phosphate & Nitrate & Chloride \\
\hline Jan. & 7.35 & 2.52 & 132.45 & 83.42 & 0.35 & 2.17 & 38.12 \\
\hline Feb. & 6.48 & 2.98 & 126.42 & 82.46 & 0.31 & 2.45 & 39.23 \\
\hline Mar. & 6.88 & 2.13 & 132.46 & 96.43 & 1.2 & 2.22 & 37.26 \\
\hline Apr. & 8.14 & 2.78 & 128.46 & 107.12 & 1.06 & 2.43 & 38.10 \\
\hline May & 8.52 & 1.56 & 142.45 & 156.26 & 0.82 & 2.46 & 42.26 \\
\hline Jun. & 8.46 & 2.47 & 131.47 & 145.72 & 0.19 & 2.17 & 41.15 \\
\hline Jul. & 8.42 & 4.23 & 152.47 & 110.49 & 0.89 & 2.45 & 43.48 \\
\hline Aug. & 8.26 & 4.23 & 158.45 & 102.45 & 0.67 & 6.48 & 42.45 \\
\hline Sept. & 8.10 & 4.59 & 148.46 & 98.24 & 1.46 & 12.45 & 41.27 \\
\hline Oct. & 8.49 & 5.58 & 162.42 & 95.47 & 1.85 & 11.56 & 40.48 \\
\hline Nov. & 8.10 & 5.98 & 158.46 & 91.46 & 1.92 & 6.42 & 42.26 \\
\hline Dec. & 8.13 & 6.12 & 152.47 & 87.48 & 1.94 & 4.23 & 39.45 \\
\hline
\end{tabular}

\section{Volume 5 Issue 4, April 2016}




\section{International Journal of Science and Research (IJSR) \\ ISSN (Online): 2319-7064 \\ Index Copernicus Value (2013): 6.14 | Impact Factor (2015): 6.391}

Surface water temperature was fluctuated between $22.28 \pm$ $0.32^{\circ} \mathrm{C}$ to $28.96 \pm 0.65^{\circ} \mathrm{C}$ at Mohanram Pond. The minimum temperature was recorded in the month of January $\left(22.16^{\circ} \mathrm{C}\right)$ and maximum in May $\left(28.64^{\circ} \mathrm{C}\right)$. The seasonal pattern in temperature fluctuation was recorded as low in winter season, while high in summer season. Swaranlatha and Rao (1998) have recorded minimum water Temperature during winter and maximum during summer (May, June) of Banjara Lake.

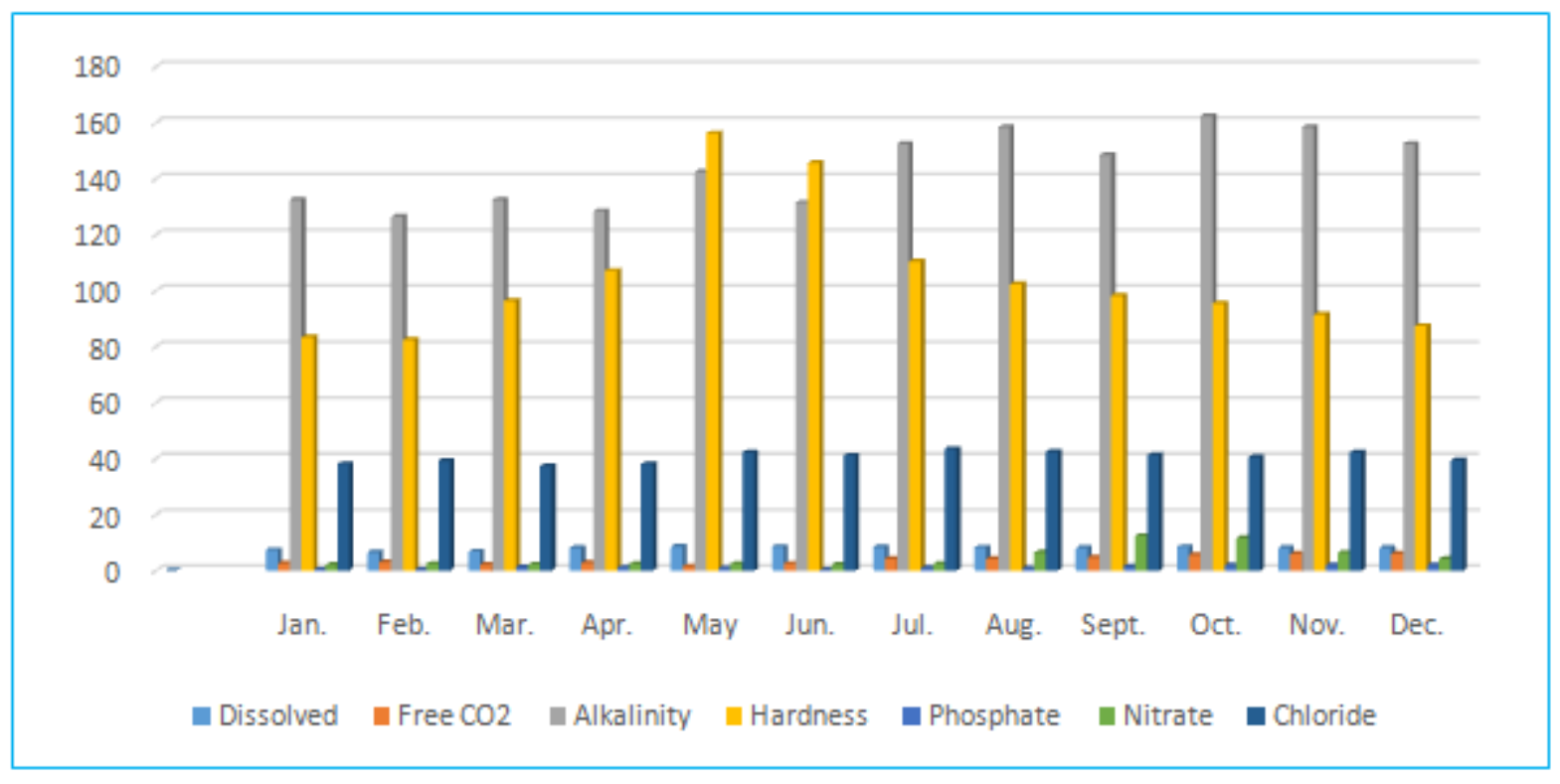

Graph 2: Chemical Parameters of Mohan Ram Pond, Distict Shahdol

Turbidity is an important limiting factor in the productivity of freshwater ecosystems. It was recorded within the range from 0.68 to 2.95 NTU. The minimum turbidity was observed in the month November of maximum in March. Arvind Kumar (1995) observed that maximum transparency value was in December and minimum in August at freshwater tropical wetland of Santhal Pargana (Bihar). Transparency is the property of water by which it allows light to pass. Light is an essential factor in freshwater environments for survival of hydrophytes and acts source of oxygen as a by Product of photosynthesis. Transparency was varied from $32.45 \mathrm{~cm}$ to $44.56 \mathrm{~cm}$. Lower transparency values were observed in February and higher in October. This pattern in transparency was also observed by Agarwal and Thapliyal (2005) in Bhilangana River from Tehri Dam reservoir of Uttaranchal. The $\mathrm{pH}$ of the water samples was alkaline throughout study period. $\mathrm{pH}$ was recorded within the range from 7.10 to 8.28. Minimum $\mathrm{pH}$ was observed in the month of March and maximum in the month of June. Altindaget al. (2009) also reported that $\mathrm{pH}$ was fluctuated between 8.18 to 8.21 in Karaman stream of Antalya, Turkey. $\mathrm{pH}$ range within 6.0 to 8.5 range is good for culturing tropical fish species (Huett, 1977) and, it is the recommended levels for drinking water (WHO, 1984): Federal Environmental protection Agency (FEPA) recommended $\mathrm{pH}$ 6.5-8.0 for drinking and 6.0-9.0 for aquatic life. The cheap rate of photosynthetic activities reduces the assimilation of carbon dioxide and bicarbonates which are eventually responsible for increase in $\mathrm{pH}$, the low oxygen values coincided with high temperature during the summer month. The factors like temperature bring about changes in the $\mathrm{pH}$ of water. The higher $\mathrm{pH}$ values observed suggests that carbon dioxide, carbonate- bicarbonate equilibrium is affected more due to change in physico-chemical condition (Karanth, 1987 and Tiwari, 1988). Change in $\mathrm{pH}$ is due to discharge of agricultural wastes, human anthropogenic activities and surface runoff.

The dissolved oxygen was recorded within the range from 6.48 to $8.52 \mathrm{mg} / \mathrm{l}$ Minimum dissolved oxygen was recorded in the month of February and maximum in the month of May. The amount of dissolved oxygen in water was not constant but fluctuates, depending on temperature, depth, wind and amount of biological activities such as degradation (Adeniji, 1986; 1993): Naz and Turkmen (2005) have reported that in summer, dissolved oxygen concentration decreased due to high temperature. The dry season showed a significantly higher oxygen content than the wet at Kangimi reservoir, Kaduna state Nigeria.

The free carbon dioxide content in the water samples of Mohan Ram Pond was within the range from 1.89 to 5.98 $\mathrm{mg} / \mathrm{l}$. High content of free carbon dioxide was recorded in the month of November and minimum in May (Sikabira, 2010) also recorded the similar results regarding free CO2 content from freshwater bodies. Alkalinity in the water samples of Mohan Ram Pond varied from 126.42 to $162.42 \mathrm{mg} / \mathrm{l}$. Minimum alkalinity was recorded in February and maximum in October. Similar observations have been made by Holden and Green (1960) and Tailing and Rzoska (1967) on Rivers Sokoto and Nile in Egypt respectively.

The hardness was fluctuated from 82.46 to $156.26 \mathrm{mg} / \mathrm{l}$. The minimum hardness was recorded in the month of February and maximum in May. The similar results were obtained by Ravichandran et al. (2009) from the study of ponds from Phosphate content was fluctuated between 


\section{International Journal of Science and Research (IJSR) \\ ISSN (Online): 2319-7064 \\ Index Copernicus Value (2013): 6.14 | Impact Factor (2015): 6.391}

0.19 to $1.94 \mathrm{mg} / \mathrm{l}$. It was observed as minimum in June and maximum in December. The phosphate content in any water body was quite opposite in relation to dissolved oxygen and phytoplankton population. Many earlier workers have also reported similar findings (Ghavzan et al., 2006).

Nitrate content in the water was recorded within the range from 2.17 to $12.45 \mathrm{mg} / \mathrm{l}$. Minimum nitrate content was observed in the month of January and maximum in September. The chloride content in water samples was recorded from 37.26 to $43.48 \mathrm{mg} / \mathrm{l}$. Minimum chloride content was recorded in the month of March and maximum in July. Chourasia and Adoni (1985) also found similar behaviour of chlorides in their studies on Sagar Lake with summer maxima and winter minima.

Almost all parameters during the present study meet the water quality norms as per BIS New Delhi. Now it is clear that, the tank is not polluted by human anthropogenic activities and agricultural runoff from surrounding areas. Hence, it is appropriate for human consumption. Moreover, pond is used for irrigation, fishery and domestic purposes. As water is not contaminated, it is potable.

\section{Acknowledgements}

Authors are thankful to Principal, Pt. S.N.S. Govt. P.G. College Shahdol (M.P.) and Dr. A.A. Khan Retd. Professor and Head Dept. of Botany Govt. Girls P.G. College Rewa (M.P.) for valuable suggestion and carried out this work.

\section{References}

[1] APHA, AWWA and WPCF, (1989). Standard method of examination of water and waste water, $20^{\text {th }}$ edn., American Public Health Association, Washington DC. USA. Pp. 1213.

[2] Aher, S.K. Mane, U.H. and Pawar, B.A. (2007). A study on physico-chemical parameters of Kagdipura Swamp in the relation to pisiculture near Aurangabad, Maharashtra

[3] Ali M. A., Salam A., Azeem M., Shafique and Khan, B.A. (2000). Studies on the effect of seasonal variations on physical and chemical characteristics of mixed water from Rivers Ravi and Chenab at union site in Pakistan. J. Res. B. Z. Univ. Multan, 2: 1-17.

[4] Arvind, Kumar (1995). Some limnological aspects of the freshwater tropical wetland of Santhal Pargana (Bihar) India. J. Env. And Poll. 2(3) : 137-141.

[5] Gray, N.F. (1994). Drinking water quality problems and solutions Chichester, UK: John Wiley and Sons.

[6] Gupta, S.K., Gupta, R.C., Gupta, A.B., Seth, A.K., Bassin, J.K. and Gupta, A. (2000). Recurrent acute respiratory infections in areas with high nitrate concentrations in drinking water. Environ Health Perspect. 108 : 363-366.

[7] Kumar, Ravindra and Jha, Arvind Kumar (2015). Physico-chemical studies on Kamla River Water, IJARCSSE, 5(5): 1411-1415.
[8] Lloyd, R. (1992): Pollution and Fresh Water Fish, Fishing News Books.

[9] Mishra, Deepti, Mudgal, Manish, Khan, Mohd Akram, Prabha Padmakaran and Chakradhar, B. (2009). Assessment of ground water quality of Bhavnagar region (Gujarat). Journal of Scientific \& Industrial Research, 68: 964-966.

[10] Sirajudeen, J and Yahith, R. Abdul (2014). Water quality assessment of groundwater resources between Tamilnadu and Pondicherry states, India. World Journal of Pharmacy and Pharmaceutical Sciences, 3(7):881-893.

[11] Tewari, Anurag, Dubey, Ashutosh and Trivei, Aviral (2010). A study on Physico-chemical characteristics of ground water quality. J. Chem. Pharm. Res., 2(2): 510-518 